\title{
Signo del Colibrí, imagen típica de la parálisis supranuclear progresiva
}

\author{
Hummingbird syndrome, typical image of progressive supranuclear palsy
}

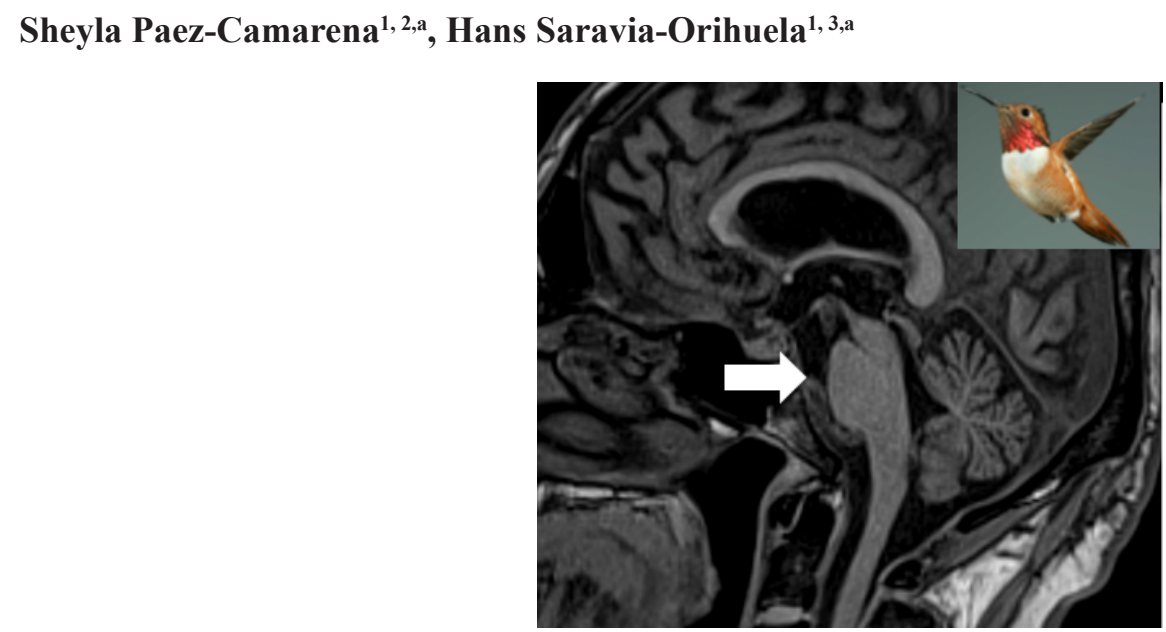

Varón de 61 años que desde hace 2 años presenta rigidez, inestabilidad postural con caídas frecuentes, alteración de los movimientos oculares (parálisis de la mirada vertical) y deterioro cognitivo leve. La imagen de resonancia magnética cerebral, en adquisición sagital ponderada en T1, muestra atrofia del tegmento mesencefálico representado por disminución de su diámetro antero posterior y concavidad de su superficie superior, con preservación de las dimensiones de la protuberancia anular, simulando la morfología de colibrí (signo del colibrí), hallazgo radiológico típico de la Parálisis Supranuclear Progresiva. Esta enfermedad neurodegenerativa secundaria a la hiperfosforilación de la proteína tau, es la segunda causa más común de parkinsonismo, de difícil diferenciación en etapas tempranas con la Enfermedad de Parkinson. Se caracteriza por atrofia del tegmento del mesencéfalo con afectación del fascículo longitudinal medial (mirada conjugada), siendo la resonancia magnética el principal método diagnostico no invasivo para la evaluación morfológica.

We present the case of a 61-year-old male who presented with a 2-year history of rigidity, postural instability with frequent falls, alteration of ocular movements (vertical gaze palsy) and mild cognitive deterioration. The magnetic resonance imaging showed in the $\mathrm{T} 1$ sequence, atrophy of the mesencephalic tegmentum characterized by a reduction in its antero-posterior diameter and concavity of its superior surface with preservation of the annular protuberance, mimicking the morphology of a hummingbird, typical radiologic finding of the progressive supranuclear palsy. This neurodegenerative disease is the result of hyper phosphorylation of the tau protein and it is the second most common cause of parkinsonism being difficult to differentiate from Parkinson's disease in its early stages. It is characterized by atrophy of the mesencephalic tegmentum with affection of the longitudinal medial fasciculus (conjugated gaze). Magnetic resonance imaging is the main non-invasive diagnostic method for this condition

\section{Correspondencia:}

Sheyla Paez-Camarena

Dirección: Jr. Hermanos Vilela $\mathrm{N}^{\circ} 191$, Urb. El Bosque - Rímac

Correo electrónico: sheyla_pc21@hotmail.com, Teléfono: 51949610305

\footnotetext{
Departamento de Radiología, Hospital Nacional Edgardo Rebagliati Martins. Lima, Perú.

Facultad de Medicina, Universidad Ricardo Palma. Lima, Perú.

Facultad de Medicina, Universidad Nacional Mayor de San Marcos. Lima, Perú.

Médico Residente de Radiología.
} 